\title{
IDEOLOGI FAMILIALISME PADA PEREMPUAN BATAK KARO DAN PEREMPUAN JAWA DI DESA PURWOBINANGUN (KAJIAN WACANA KRITIS)
}

\author{
Sri Ulina Beru Ginting \\ STKIP Budidaya Binjai \\ linaginting31@gmail.com
}

\begin{abstract}
ABSTRAK
Ideologi familialisme merupakan suatu jebakan dimana menempatkan perempuan hanyalah sebagai istri yang baik dan ibu yang baik.Perempuan harus bisa berhias diri untuk bisa memberi pelayanan yang terbaik bagi suami. Pada suku Karo dan suku Jawa di Desa Purwobinangun, ideologi familialisme sangat dijunjung tinggi meskipun suatu jebakan bagi mereka, karena perempuan Karo dan perempuan jawa di Desa Purwobinangun adalah perempuan yang pekerja keras, apapun dilakukan demi keluarga dan anak-anaknya. Perempuan Karo mempunyai tanggung jawab yang besar di dalam keluarga, baik di keluarga mertuanya maupun dikeluarga orang tuanya. Karena di keluarga mertua perempuan Karo kedudukannya sebagai Kalimbubu, di keluarga orang tuanya perempuan Karo posisinya sebagai sebagai anak beru. Adapun tujuan dari penelitian ini adalah untuk mengetahui bagaimana perempuan Karo dan perempuan jawa menjalankan bentuk dari ideolgi familialisme. Metode dalam penelitian ini adalah kulitatif deskriftif dan mengunakan pendekatan fenomenologi. Teknik pengumpulan data dalam penelitian ini mencakup: Observasi, wawancara , Dokumentasi. Ideologi familialisme pada perempuan Karo dan perempuan Jawa tergambar bagimana perempuan pekerja keras yang memperjuangkan agar orang-orang yang ia kasihi mendapat yang terbaik di dalam kehidupannya, tanpa memperhitungkan pengorbanan baik moril maupun materil.

Gambaran potret budaya Familialisme pada perempuan Karo dan perempuan Jawa , dimana seorang ibu yang baik itu pasti memperjuangan segala bentuk apapun demi memenuhi kebutuhan hidup anak-anaknya agar dapat bersekolah kejenjang yang lebih baik serta juga harus mampu merias diri untuk member pelayanan yang terbaik bagi suami.Pengorbanan inilah yang akan mengangkat status social keluarag ketika anak anak yang mereka perjuangkan berhasil.
\end{abstract}

kata kunci : ideologi familialisme, perempuan Karo, perempuan Jawa, wacana kritis

\section{PENDAHULUAN}

Identitas gender merupakan perasaan subyektif tentang keberadaan seseorang sebagai laki-laki atau perempuan dan merupakan bagian penting dari seseorang. Pada etnik Karo terkadang muncul ketidak adilan gender dengan laki laki, di mana upah laki laki bekerja lebih besar dari pada upah perempuan bekerja di ladang petani. Dalam kehidupan perempuan turut serta dalam menopang kehidupan keluarga, peran perempuan Karo sudah jauh berbanding 


\section{Jurnal Serunai Bahasa Indonesia \\ Vol.16, No.1, Februari 2019 \\ e-ISSN 2621-5616}

terbalik dengan ideologi gender, di Desa Purwobinangun mayoritas mata pencaharian penduduknya adalah petani, di mana mereka harus berangkat keladang jam setengah delapan pagi dan akan tiba kembali di rumah jam dua belas siang, aktifitas mereka di ladang membersihkan rumput yang ada di antara tanaman, memupuk tanaman dan memanen hasil pertanian.

Ideologi Familialisme merupakan suatu jebakan dimana menempatkan perempuan hanyalah sebagai istri yang baik dan ibu yang baik.Perempuan harus bisa berhias diri untuk bisa memberi pelayanan yang terbaik bagi suami. Pada suku Karo dan suku Jawa di Desa Purwobinangun , Ideologi familialisme sangat dijunjung tinggi meskipun suatu jebakan bagi mereka , karena perempuan Karo dan perempuan jawa di Desa Purwobinangun adalah perempuan yang pekerja keras, apapun ia lakukan demi keluarga dan anak-anaknya. Perempuan Karo mempunyai tanggung jawab yang besar didalam keluarga,baik di keluarga mertuanya maupun dikeluarga orang tuanya. Karena di keluarga mertua perempuan Karo kedudukannya sebagai Kalimbubu, di keluarga orang tuanya perempuan Karo posisinya sebagai sebagai anak beru.

Dari hasil pengamatan peneliti, perempuan di desa Purwobinangun yang sangat berperan menopang kehidupan perekonomian didalam keluarga, pada saat jam kerja mereka melaksanakan tugasnya di ladang sementara kaum laki laki menghabiskan waktunya duduk duduk santai di kedai kopi sambil bermain catur, tanpa ada rasa prihatin melihat istri mereka yang banting tulang di bawah terik matahari mengerjakan lahan pertanian mereka. Kaum lakilaki turut serta ke ladang apabila tanaman pertanian mereka ada yang panen, pada umumnya tanaman yang ditanam adalah tanaman palawija. Dari pemaparan diatas terbentuklah profil gender Nrimo, pasrah, tidak banyak tuntutan, dan selalu berusaha menutup diri, agar semuanya berjalan aman, tidak menimbulkan konflik, baik di lingkungan keluarga maupun masyarakat.

Berdasarkan latar belakang di atas dapat dilihat secara kasat mata perbedaan ideologi gender antara kaum laki-laki dan kaum perempuan Karo dan perempuan Jawa di desa Purwobinagun, secara umum dapat dikatakan kajian perempuan atau analisis gender mencoba mengangkat kepermukaan sehingga keadilan dan kesetaraan gender secara struktural dan kultural dapat diwujudkan. Dengan kata lain dapat dikatakan analisis gender bukan sekedar kajian tentang perempuan, tetapi juga kajian terhadap isu perempuan, perspektif perempuan, 
kepentingan perempuan,perbaikan kedudukan dan peran perempuan, sejarah perempuan, sosok perempuan. Dalam penelitian ini akan membahas " ideologi Familialisme pada perempuan Batak Karo dan Perempuan Jawa di Desa Purwobinangun Kajian wacana kritis".

\section{METODE}

Metode penelitian yang digunakan peneliti ini adalah metode kualitatif deskriptif analisis. Metode penelitian ini mengkaji antara lain menentukan lokasi pelaksanaan penelitian, teknik pengumpulandata,analisis data, menentukan sumber data, jadwal penelitian, sertamerincikan luaran penelitian pertahun dan indikator capaian. Peneliti fokus dalam tiga tahapan kegiatan terhadap objek penelitian yang mencakup (1) Pengumpulan data (2) Pengolahan data (3) Penganalisisan data untuk memperoleh hasil dari Idiologi familialisme yang terkandung pada perempuan Karo dan Perempuan Jawa.

Penelitian ini dilaksanakan di Dusun V Sumber Muliyo dan Dusun VI Serbajadi Desa Purwobinangun Kecamatan.Sei. Bingai Kabupaten Langkat. Subjek yang diambil dalam penelitian ini adalah Masyarakat suku Karo dan suku Jawa yang berdomisili di Desa PurwoBinangun Kecamatan Sei-Bingei, Kabupaten Langkat. Objek dalam penelitian ini adalah perempuan yang bersuku Karo dan perempuan bersuku Jawa yang berdomisili tetap di Desa Purwobinagun Kec. Sei.Bingai Kabupaten Langkat.

Dengan demikian, peneliti ikut terlibat langsung dalam aktifitas yang akan diteliti dalam pengumpulan data. Metode dan teknik pengumpulan data dalam penelitian ini mencakup : (1) Observasi (2) wawancara (3) Dokumentasi.

\section{HASIL DAN PEMBAHASAN.}

\section{HASIL}

Penelitian yang dilakukan oleh peneliti di Desa Puwobinangun, dimana peneliti menemukan bentuk Ideologi familialisme pada perempuan Batak Karo dan perempuan Jawa yaitu 


\section{Ideologi Familialisme Pada Perempuan Karo}

Merujuk pendapat (Bhasin dalamYoce 2017:175) meyatakan ideologi familialisme merupakan ideologi yang mengkontruksi perempuan berperan di rumah tangga, sebagai ibu rumah tangga, istri yang baik, ibu yang baik. Pada perempuan Karo ideologi familialisme sangat dijunjung tinggi, karena perempuan Karo adalah perempuan yang pekerja keras, apapun ia lakukan demi keluarga dan anak-anaknya. Perempuan Karo mempunyai tanggung jawab yang besar didalam keluarga, baik di keluarga mertuanya maupun dikeluarga orang tuanya. Karena di keluarga mertua perempuan Karo kedudukannya sebagai Kalimbubu, di keluarga orang tuanya perempuan Karo posisinya sebagai sebagai anak beru.

Ideologi familialisme pada perempuan Karo dapat kita dilihat pada penuturan ibu L Br Ginting, dimana beliau menuturkan kepada peneliti sewaktu ia masih kecil orang tuanya sudah mendidik ia sebagai perempuan yang mandiri dan pekerja keras dan penuh tanggung jawab didalam keluarga. Bagaimana ia harus bersikap kelak setelah menikah apa yang harus ia lakukan semua ia masih ingat dari didikan orang tuanya meski usianya disaat itu masih belia.

Saya masih ingat apa yang dikatakan oleh ibu saya meski beliau sudah 19 tahun tiada,saya harus menjadi ibu yang baik bagi anakanak saya dan menjadi istri yang baik bagi suami di tengah-tengah keluarga.Tanggung jawab mengurus anak adalah sepenuhnya tanggung jawab saya, suami bekerja untuk mencari nafkah untuk membiayai anak-anak agar dapat sekolah, kamu harus mendidik anak-anak kamu dengan baik agar lelah suamimu mencari uang tidak sia sia. Syukurlah kedua anak saya setelah dewasa menjadi anak yang baik dan mengerti terhadap keadaan orang tuanya, tanggung jawab saya sebagai orang tua sudah saya laksanakan hingga menghantar mereka ke gerbang sarjana.

Penuturan ibu L.Br ginting menandakan bagai mana amanat yang di sampaikan oleh alm ibunya merupakan suatu motivasi yang besar, karena ibu yang baik mampu mendidik dan mengantarkan anak-anaknya hingga mencapai kesuksesan. Dimana ke dua anak ibu L Br Ginting sudah tamat sarjana dan itulah membuat ia bangga sebagai perempuan Karo yang mampu ia hadapi dimasa-masa sulit sekalipun dalam aturan adat.

Keberhasilan didalam sebuah keluarga tidak terlepas dari peran seorang perempuan, baik itu kedudukannya sebgai seorang istri atau sebagai anak 
perempuan yang bertanggung jawab seperti penuturan ibu S Br Tarigan berikut ini:

“ Sebagai seorang ibu dan seorang kakak saya merasa bertanggung jawab terhadap keluarga dan adik adik saya. Meskipun saya harus ikat pinggang saya harus mampu menyekolahkan anak saya dan mendidik adik adik saya hingga mereka berhasil”.

Pada penyataan diatas tergambar jelas rasa tanggung jawab ibu $\mathrm{S} \mathrm{Br}$ Tarigan yang begitu besar terhadap anak-anaknya dan adiknya ia selalu berusaha memberi hal yang terbaik, karakter ibu S Br Tarigan tergambar perempuan pekerja keras yang memperjuangkan orang-orang yang ia kasihi mendapat yang terbaik di dalam kehidupannya, tanpa memperhitungkan pengorbanan baik moril maupun materil. Terlihat juga pada pernyataannya yang menuturkan :

“ Rasa lelah itu terbayar semua ketika anak saya di wisuda, dan adik saya terdidik semua, perjuangan saya tidak sia-sia karena anak saya berhasil menyelesaikan pendidikannya, walupun saya tidak diperlakukan oleh orang tua saya sebaimana yang saya inginkan. tapi saya tidak melakukan demikian terhadap anak perempuan dan anak laki-laki saya. Puas rasanya hati dan perasaan saya sebgai seorang ibu dan sebagai seorang kakak".

Bentuk ideologi familialisme tergambar jelas pada pernyataan ibu $\mathrm{S} \mathrm{Br}$ Tarigan ketika anaknya di wisuda dan adik-adiknya terdidik, merupakan suatu hal yang luar biasa bagi diri ibu Tarigan, rasa lelahnya hilang karena melihat apa yang ia harapkan berjalan sesuai dengan harapan. Tergambar bagaimana ia berhasil menyekolahkan anak anaknya hingga di perguruan tinggi dan adik adiknya mendengarkan dan menjalankan didikannya. Keberhasilan pada perempuan Karo yang dilakukan oleh ibu Tarigan mengambarkan ia sebagai seorang Nande (ibu) yang bertanggung jawab terhadap keluarga.

\section{Ideologi Familialisme Pada Perempuan Jawa}

Merujuk pendapat ( Bhasin dalamYce 2017:175) meyatakan idiologi familialisme merupakan idiologi yang mengkontruksi perempuan berperan di rumah tangga, sebagai ibu rumah tangga, istri yang baik, ibu yang baik, Ideologi Familialisme yang di temukan peneliti pada saat penelitian melakukan wawancara dan saat menganalisis angket pertanyaan dari responden antara lain terlihat pada 
saat peneliti mewawancarai ibu Legiati yang menyatakan ia harus menjadi ibu rumah tangga yang baik dan istri yang baik bagi keluarganya ketika beliau menuturkan:

"Suami saya melarang saya untuk bekerja, ia hanya menyuruh saya untuk mengurus keluarga dan anak anak padahal saya tamat sekolah perawat kesehatan. Suami saya takut jika saya bekerja anak-anak jadi terlantar dan tidak ada yang memperhatikan.Orang tua saya juga mengatakan saya harus patuh pada suami jika ingin menjadi istri yang baik. ya saya Pasrah dan trima ajalah jadinya. Memang sih kebutuhan keluarga terpenuhi semuanya oleh suami”.

Pada penuturan ibu Legiati diatas tergambar jelas untuk menjadi istri dan ibu yang baik harus patuh pada suami seperti yang dituturkan oleh orang tuanya. Karena pemahaman orang tua ibu Legiati, istri yang baik dan ibu yang baik itu adalah istri yang patuh pada aturan suaminya. Padahal aturan suami ibu legiati itu sudah membatasi ruang geraknya sebagai seorang perempuan yang memiliki pendidikan yang dapat ia aplikasikan di masyarakat. namun pada kenyataannya ibu Legiati ya harus tunduk atas apa yang di sampaikan suaminya karena dengan tidak bekerja kebutuhan hidup di keluarga sepenuhnya terpenuhi oleh pendapatan suaminya.

Masyarakat dusun V sumber Mulio yang mayoritas penduduknya bersuku Jawa terkadang pengaruh lingkungan juga sudah hampir memiliki karakter yang keras, hal ini mungkin karena faktor lingkungan yang menuntut mereka menjadi perempuan pekerja keras. Seperti yang ditemukan peneliti di lapangan, bentuk dari ideologi Familialisme juga dapat kita lihat pada penuturan ibu Sinem sewaktu peneliti melakukan wawancara terhadap responden yang menjadi objek penelitian:

"Pekerjaan ini saya lakukan adalah agar anak-anak saya bisa sekolah dan kelak ia tidak bekerja seperti saya menjadi buruh upah mengaco dodol atau buruh upah megerjakan ladang. Walaupun panas terik matahari membakar kulit saya tak masalah bagi saya agar anak saya bisa sekolah.Karena anak-anak adalah titipan Tuhan kepada saya.mereka harus mendapat pendidikan yang baik.saya tidak mengharapakan imbalan apa apa dari anak jika kelak mereka sukses. melihat mereka bahagia saja saya sudah bahagia”. 
Penuturan ibu sinem merupakan potret budaya Familialisme dimana seorang ibu yang baik itu pasti memperjuangan segala bentuk apapun demi memenuhi kebutuhan hidup anak-anaknya agar dapat bersekolah. Ketika ia juga mengatakan disaat anaknya sakit dan ia tidak memiliki uang untuk berobat, karena waktu itu belum ada BPJS saya kesana kemari mencari pinjaman. Apapun saya lakukan agar anak saya bisa berobat, karena banyak yang bilang jika terlambat tertolong anak saya bisa meninggal. Terlihat rasa sedih dan rasa takutnya ia kehilangan anaknya pada dialok berikut ini:

Uang sepeserpun tak ada di tangan, anak kena DBD harus di obname di rumah sakit.Disitu saya tidaklagi tau harus berbuat apa. saya tidak malu lagi mengutang sama kepala desa agar anak saya bisa berobat. Dalam otak saya hanya terbayang jika anak saya terlambat ditangani bisa mati, anak saya harus bisa sembuh dan sehat kembali. Hanya doa yang saya ucapkan sepanjang jalan hingga tiba di rumah pak kades.

Rasa kasih sayang seorang ibu begitu besar terhadap anaknya, hingga apapun ia mau lakukan agar anaknya dapat sehat kembali, hal yang tak pernah ia lakukan meminjam kepada kepala desa pun ia lakukan dan mengabaikan rasa gengsi dan malunya untuk mendapat menyembuhakn anaknya. karena ibu yang baik adalah ibu yang mampu memperjuangkan orang orang yang ia kasihi yaitu keluarga.

Penelitian ini menggunakan pendekatan observasi fenomenologi dimana pengamatan langsung yang terdapat pada masyarakat dusun V di Sumber Muliyo dan dusun VI Serbajadi dan apa yang terjadi pada perempuan Batak Karo dan dan perempuan Jawa, karena fenomenologi yang terjadi dimasyarakat desa Purwobinagun dimana kaum perempuan merepresentasikan perannya melalui berbagai aspek-aspek bagaimana mereka memposisikan dirinya di keluarga, di dalam adat dan di masyarakat.

Dalam wacana kritis yang di kembangkan oleh Norman Faiclough dalam Yhoce dimana analisis farming, yang berisi metode-metode yang menekankan multilevel analysis yang mempertaukan analisis pada jenjang meso atau macro dan memusatkan bahasa sebagai praktek kekuasaan. Bahasa secara sosial dan historis ialah bentuk tindakan dalam hubungan dialektik dengan struktur sosial .Oleh karena itu, alasisi harus di pusatkan bagaimana bahasa itu 


\section{Jurnal Serunai Bahasa Indonesia \\ Vol.16, No.1, Februari 2019 \\ e-ISSN 2621-5616}

terbentuk dan dibentuk dari relasi sosial dan koneks sosial tertentu. Kekritisan kaum perempuan mengubah paradikma gender dimana dimasa sekarang ini terjadi perubahan gender karena tuntutan ekonomi kehidupan dimana peran istri yang dulunya hanya sebagai ibu rumah tangga kini sudah ikut untuk menambah penghasilan keluarga, membantu suami bekerja utuk mendapat uang tambahan. Wacana mengenai perempuan telah banyak diteliti dengan menggunakan berbagai analisis seperti dalam pernyataan Ammalia dalam jurnal yang berjudul Wacana Peran Perempuan dalam Kolom Story Rubrik For Her Surat Kabar Jawa Pos..

\section{PEMBAHASAN}

Dari hasil pengumpulan data dan penganalisisan data terlihat jelas bahwa perempuan Batak Karo dan perempuan Jawa di Desa Purwobinagun merupakan perempuan yang mandiri dimana mereka tidak tergantung pada suami sebagai sumber ekonomi keuangan di keluarga. Kreatif dan inovatif memiliki semanagat dan jiwa jiwa perubahan dalam menyikapi berbagai fenomena didalam keluarga.

Perempuan Batak Karo dan perempuan Jawa memiliki jiwa kepemimpinan, mereka mulai mampu melawan dominasi laki-laki, sehingga mereka mampu membuktikan kepada semua orang bahwa perempuan memiliki kemampuan yang sama dengan laki-laki serta mampu membantah asumsi patriarkis yang sangat berkembang. Pada suku Karo anak laki-laki yang paling dianggap bertanggung jawab terhadap kedua orang tuanya kelak di hari tua, anak laki-laki yang akan mengurus ayah ibuya disaat sudah tua. sedangkan anak perempuan dianggap hanya sebagai pendamping di dalam keluarga. Tapi pada kenyataannya sekarang di desa purwobinangun justru di anak perempuannlah orang tua mereka tinggal dan anak perempuanlah yang mengurus kedua orang tuanya.

Dalam kenyataan sebenarnya anak laki-laki hanya sebagian kecil yang mengurus orang tuanya, justru anak perempuanlah yang mengurus orang tuanya, dilihat dari pengamatan yang dilakukan oleh peneliti terhadap beberapa sumber responden. Gender yang muncul karena adanya pengaruh sosial dan kultural menyebabkan ketimpangan-ketimpangan dalam masyarakat. Sistem patriarki yang dominan erat dalam kehidupan masyarakat menyebabkan ketidakadilan pada salah 
satu jenis kelamin yaitu perempuan. Dalam Tanita (2016:207) menyatakan perempuan dianggap sebagai makhluk kelas dua. makhluk lemah,tidak berdaya, emosional, dan pekerja rumahan. Seperti yang telah di paparkan oleh peneliti bahwasanya tradisi perkawinan pada suku Karo merupakan sitem patrilineal dengan sistem ini jelas-jelas merupakan perwujudan dari ideologi patriarki, dimana laki-laki diposisikan lebih tinggi daripada perempuan, perempuan harus dikontrol oleh laki-laki dan perempuan diposisikan sebagai milik laki-laki. Sistem patrilineal juga menyangkut hukum waris, dimana hak milik diwariskan bapak kepada anak laki-laki, tidak pada perempuan. Ketika anak perempuan menikah, dia tidak membawa apa-apa sebagai aset ekonomi kedalam lingkungan keluarga suaminya. Anak laki-lakilah yang lebih dominan di dalam keluarga pada suku Karo.

Dalam penuturan responden ketika di wawancarai dan dari hasil analisis angket pertanyaan yang di bagi peneliti pada sumber objek penelitian yaitu pada permpuan Batak Karo dan perempuan Jawa di Desa Puwobinangun, dimana hasil penelitian yang dilakukan peneliti, peneliti menemukan bagaimana perempuan Karo dan perempuan Jawa cenderung ber empati terhadap ideology familialisme di Desa Purwobinagun Kecamatan Sei.Bingai. Dalam penelitian ini kenapa perempuan harus berpendidikan? karena kehidupan kedepannya ia setara dengan pria, bukan menghilangkan sosok kodrat sebagai kaum perempuan, karena kaum laki-laki sering berpikir bahwa kaum wanita hanya mampu menghabiskan uang mereka. Jika perempuan memiliki penghasilan dalam pekerjaan tidak akan ada kaum laki -laki yang merendahkan derajat kaum perempun.

Didalam kehidupan sehari hari sudah ada pembagian tugas dan tangung jawab orang tua terhadap anak. Dulunya orang tua sebagai bapak hanya berperan sebagai pencari nafkah untuk keluarga , tanpa harus memikirkan membantu istri dalam mengurus, merawat dan membesarkan anaka anak. Kini perempuan karo dan perempuan jawa sudah mulai mendominasi apa yang dilakukan oleh kaum pria. 


\section{SIMPULAN}

Setelah peneliti melakukan pengumpulan data, data diolah menjadi data yang akurat. Dari hasil penelitian di Dusun V Sumber Mulio dan Dusun VI Serbajadi Desa Puwobinangun, maka peneliti menyimpulkan :

1. Ideologi familialisme sangat dijunjung tinggi, karena perempuan Karo adalah perempuan yang pekerja keras, apapun ia lakukan demi keluarga dan anakanaknya. Perempuan Karo mempunyai tanggung jawab yang besar didalam keluarga, baik di keluarga mertuanya maupun dikeluarga orang tuanya. Karena di keluarga mertua perempuan Karo kedudukannya sebagai Kalimbubu, di keluarga orang tuanya perempuan Karo posisinya sebagai sebagai anak beru.

2. Bentuk Ideologi familialisme pada perempuan Batak Karo dan perempuan Jawa yang ditemukan peneliti pada saat melakukan penelitian di Desa Purwobinagun yaitu. potret budaya Familialisme dimana seorang ibu yang baik itu pasti memperjuangan segala bentuk apapun demi memenuhi kebutuhan hidup anak-anaknya agar dapat bersekolah. Adanya rasa kepedulian seorang ibu pada perempuan Batak Karo dan Perempuan Jawa terhadap dibidang pendidikan dan pekerjaan bagi anak anak perempuan mereka, meskipun demikian perlawanan ini tidak bertentangan dengan aturan adat. Dimana dulunya pada masa mereka, anak perempuan tidak di prioritaskan dalam sekolah keperguruan tinggi dan dalam mengambil pekerjaan oleh orang tua mereka, orang tua lebih mengutamakan anak laki-laki dibanding anak perempuan.

\section{REFERENSI}

Anna. Rindhian Tika. Perempuan Pebisnis Dalam Budaya Jawa Di Semarang. Jurnal

Ammalia,Agustya2013..Wacana Peran Perempuan Dalam Kolom Story Rubrik For Her Surat Kabar Jawa Pos. Jurnal sastra Indonesia .JSI 2 (1)

Anugriaty.2015.Bias Gender Sebagai Prediktor Kekerasan Dalam Rumah Tangga. Jurnal Psikologi.UGM.Volume 35.No.1,1-20. 
Dagun.Save.M. 2009.Maskulin dan Feminim.Jakarta Rineka Cipta

Fakih, Mansour.2013. Analisis Gender dan Transformasi Sosial. Yogyakarta: Pustaka Pelajar.

Farah Dina, Representasi ideologi patriarki Dalam Novel Tanah Tabu Kajian Feminisme Radikal. Jurnal sastra Indonesia .JSI 2 (1) 2013.

Ginting,Sri Ulina. \& Barus.Efendi.2017. Bentuk Kesantuna Berbahasa Dalam Tindak Tutur Perkawinan Adat Karo.Tangerang : Mahara Publishing.

Mahsun,M.S. 20011.Metode Penelitian Bahasa Tahapan Strategi, Metode, dan Tekniknya. Jakarta: Rajawali Pers

Moleong.Lexy.J.2014.Metode Penelitian Kualitatif(EdisiRevisi).Bandung:Remaja Rosdakarya

Rhesa Zuhriya.2015. Pola Komunikasi Perempuan Dalam Mengkrontksi Identitas Gender Pada Gerakan PKK.Jurnal Of Rural and Development. VolumeVI No.1 Febuari.Hal 85-100 